\title{
Characterization of Autochthonous Bacteria Capable for Degradation of Residual Organic Pollutants of Pulp Paper Mill Effluent by Biostimulation Process
}

\author{
Pooja Sharma $^{1}$ (D) Sonam Tripathi ${ }^{1}$ (D), Preeti Chaturvedi ${ }^{2}$ id and Ram Chandra ${ }^{1 *}$ (D) \\ ${ }^{1}$ Department of Environmental Microbiology, School for Environmental Sciences, Babasaheb Bhimrao \\ Ambedkar Central University, Vidya Vihar, Rae Bareli Road, Lucknow - 226 025, India. ${ }^{2}$ Aquatic Toxicology \\ Laboratory, Environmental Toxicology Group, Council of Scientific and Industrial Research-Indian Institute of \\ Toxicology Research (CSIR-IITR), Vishvigyan Bhavan, 31, M.G. Marg, Lucknow - 226 001, India.
}

\begin{abstract}
The purpose of this study is remediation of residual organic pollutants from effluent by autochthonous bacterial community in biostimulation process. Discharged effluent showed high TDS (549 $\left.\mathrm{mg} \mathrm{L}^{-1}\right)$, TSS (59 $\left.\mathrm{m} \mathrm{L} \mathrm{L}^{-1}\right)$, COD (20349 $\left.\mathrm{mg} \mathrm{L}^{-1}\right)$ and BOD (25946 $\left.\mathrm{mg} \mathrm{L}^{-1}\right)$, value. The level of total phenol (421 $\left.\mathrm{mg} \mathrm{L}^{-1}\right)$, nitrogen (156 mg L $\left.{ }^{-1}\right)$, sulphate $\left(1854 \mathrm{mg} \mathrm{L}^{-1}\right)$, phosphorus $\left(176 \mathrm{mg} \mathrm{L}^{-1}\right)$ chlorine $\left(2.01 \mathrm{mg} \mathrm{L}^{-1}\right)$, sodium (75 $\left.\mathrm{mg} \mathrm{L}^{-1}\right)$ and potassium (8.4 $\mathrm{mg} \mathrm{L}^{-1}$ ) along with various heavy metals ( $\mathrm{Fe}, 75.23 ; \mathrm{Zn}, 15.60 ; \mathrm{Cu}, 4.1 ; \mathrm{Cr}$, 3.12; $\mathrm{Cd}, 0.324 ; \mathrm{Mn}, 13.24$; and $\mathrm{Ni}, 4.01 \mathrm{mg} \mathrm{L}^{-1}$ ) were noted above the permissible limit of Environmental Protection Act. The result revealed that the reduction of the physico-chemical parameter of pollutants were above $50 \%$ after biostimulation process, this confirmed the potentiality of growing autochthonous bacterial community responsible for bioremediation. The comparative UV-Vis spectroscopy showed reduction in the absorption spectra of degraded sample. Further, GC-MS analysis showed major organic pollutants i.e. Octadecanoic acid, Hexadecanoic acid, citral, benzoic acid, and 2, 6' -Di-hydroxy acetophenone, bis (trimethylsilyl) ether, were detected in control few compounds were degraded while there was formation of some new metabolic products also. Few pollutants persisted in the degraded sample as recalcitrant toxicant and causes environmental toxicity and hormonal imbalance as endocrine-disrupting chemicals (EDCs). But the detailed knowledge and characterization of organic pollutants are not available yet regarding their properties. The SEM image showed the diversity of bacterial community in biostimulation responsible for utilisation of various detected compounds. The growing bacterial communities were identified as potential bacterial strains as Aeromonas salmonicida, BBAUPS-1 (MN294457.1) and Bacillus sp. BBAUPS-2 (MN238724.1) responsible for the remediation of residual organic pollutants. Further, Evaluation of toxicity parameter of effluent by seed germination test of Triticum aestivum and Cicer arietinum inhibited the seed germination upto $80 \%$. Hence, this study revealed that the biostimulation process is a good technique for detoxification and degradation effluent.

Keywords: Environmental toxicity, endocrine-disrupting chemicals, organic pollutants, phytotoxicity, effluent detoxification
\end{abstract}

(C) The Author(s) 2020. Open Access. This article is distributed under the terms of the Creative Commons Attribution 4.0 International License which permits unrestricted use, sharing, distribution, and reproduction in any medium, provided you give appropriate credit to the original author(s) and the source, provide a link to the Creative Commons license, and indicate if changes were made. 


\section{INTRODUCTION}

The discharged effluent from the pulp paper industry contains more than 700 organic and inorganic pollutants that are directly responsible to cause the soil and water pollution after biological and chemical treatment ${ }^{1}$. The pulp paper industry ranks $6^{\text {th }}$ among the world's most polluting industries and generate large-scale hazardous pollutants during the making of papers ${ }^{2}$. Pulp paper industry effluents contain high number of complex matrices along with many other diverse compounds ${ }^{3}$. Moreover, the effluents may contain more than 250 identified chemicals and harmful components like sterols and asresin acids ${ }^{4,5}$. These compounds may end up as sediments in the water bodies and serve as food for fish and benthos ${ }^{6}$. Although, many harmful substances are removed before release by modern wastewater purification processes but some are released unintentionally into the environment. Moreover, untreated effluent with heavy nutrient load and wood derived bioactive substances if released into the natural water bodies may cause oxygen depletion and subsequent decline in the biodiversity ${ }^{7}$.

In India, there are approximately 650 small and large scale paper industries discharging approximately $190-200 \mathrm{~m}^{3}$ effluent per ton of paper production as aquatic pollutants ${ }^{8}$. Furthermore, the recent study has also revealed that some of these compounds showed EDCs effects on aquatic organisms. Moreover, there is still a lack of detailed knowledge on the estrogenic and androgenic compounds from pulp paper industry effluent and their toxicity in the aquatic organism. Therefore, optimizing bacterial growth conditions by adding different nutrients and providing good environmental conditions might be an effective strategy for detoxification. However, there is lack of understanding on the controlling factors for biodegradation of complex organic pollutants derived from several polluted sites. In-situ bioremediation has been introduced as an cost effective and less tedious approach in redeveloping any contaminated site. Additionally, the identity of the microbial community and required environmental conditions should be detected before specification for bioremediation function. Three types of bioremediation processes are generally used for the in-situ bioremediation process of any complex industrial contaminants viz. natural attenuation, bio-stimulation and bioaugmentation.

Bio-stimulation process involves adaptation to the contaminated site to provide a favourable environment for bacterial communities for effective natural degradation of different pollutants ${ }^{9}$. Several persistent organic pollutants (POPs) are present in industrial wastes which are known to be silent environmental killers due to their bio accumulative and longlasting existence ${ }^{10,11}$. Furthermore, isolated bacterial strains from compost soil i.e. Azotobacter $s p$. and Serratia marcescens might degrade and decolorize lignin-containing effluents while Bacillus subtilis and Bacillus $s p$. are responsible for kraft-lignin degradation ${ }^{12}$. The quality of water is highly detoriated by surpassing TDS, TSS, BOD and COD values. Moreover, the dark colour and high turbidity of effluent due to suspended solids, TSS, TDS and TS can further cause river pollution and compromise the drinking water quality. The pulp paper industry effluent absorbs more light and reduces the oxygen concentration in water thereby affecting the aquatic life due to presence of tannins and resin acids ${ }^{13}$. While the change in the colour and water quality nearby the industrial area makes it unsafe for drinking purpose. The leaching property of different effluent pollutants is a major source of ground pollution. Pollution of our environment by heavy metals particles is a very dangerous and challenging problem for the country ${ }^{14,15}$. Earlier, three potential bacterial strains viz. Panibacillus sp. Aneurinibacillus aneurinilyticus and Bacillus $s p$. were identified and characterized from sludge for synthetic lignin degradation and metabolic properties using gas chromatographymass spectrometry (GC-MS) analysis respectively ${ }^{16}$. Similarly, the Bacillus sp. and Serratia marcescens were also reported to cause degradation of the pentachlorophenol containing effluent in the presence of about $94 \%$ nutrients in optimized in-vitro conditions. Thus, these studies report the degradation and detoxification capability of bacteria for chlorolignins containing effluent ${ }^{17}$. The removal of heavy metals from contaminated water and soil by employing electro-coagulation for the waste management methods has been previously described ${ }^{18,19}$. Therefore, the present study was designed to focus on the characterization and identification of residual organic pollutants and 
their phytotoxicity for ecological risk assessment. However, during the biostimulation process, the role of microbes is very interesting and important for the remediation of these pollutants. Furthermore, 16s rRNA sequencing of two potential bacterial strains isolated during the biostimulation process is important. This will lead to develop in-situ bioremediation technology for the removal of color and reduce the toxicity in the effluent to prevent pollution prevention. The industry (K R pulp paper mill Ltd) selected for sampling, discharges huge amount of effluent (200 $\mathrm{m}^{3}$ of effluent/ton of paper production) which pollutes the environmental pollution and also deteriorates the surface water quality. Additionally, the observation reveals the leaching of pollutants to groundwater and soil which adversely affect human health, but the toxicity data is not published.

\section{MATERIAL AND METHODS}

\section{Site description and sample Collection}

The fresh effluent samples were collected from the M/s K R Pulp Paper Industry, Shahjahanpur, Uttar Pradesh, India (2750'31.8” N $\left.79^{\circ} 51^{\prime} 15.7^{\prime \prime} \mathrm{E}\right)$. The industry uses bagasse and bamboo woods as raw materials and generates 100 tons per day (TPD) effluents after the pulping and bleaching processes. The effluent samples were collected using a sterile plastic container and stored at $4^{\circ} \mathrm{C}$ until further use.

\section{Physico-chemical analysis}

The physico-chemical parameters of effluent were analysed as per standard methods described for the examination of water and wastewater $^{20}$. The $\mathrm{pH}$, TSS, TDS, TSS, electric conductivity (EC), chloride, sodium and potassium of the effluent were measured using the selective ion electrode of Thermo Orion, USA (Model 960). Lignin and the chlorophenols were estimated as per the method described by Chandra et al., $(2009)^{21}$. While, the heavy metals i.e. Fe, $\mathrm{Zn}, \mathrm{Cu}$, $\mathrm{Cr}, \mathrm{Cd}, \mathrm{Mn}$, and $\mathrm{Ni}$ were analysed using the atomic absorption spectrophotometer (AAS; ZEEnit 700, Analytic Jena, Germany)

\section{UV- Vis spectrophotometer analysis}

UV-Vis spectrophotometer (Thermo Fisher Scientific Shanghai Spectrophotometer Evolution 2001, China) was used to analyse the absorbance of the different organic and inorganic pollutants present in the effluent. A total of $250 \mathrm{ml}$ effluent sample in Erlenmeyer flask was amended with different concentrations of additional nutritional sources viz. glucose $1 \%$ (carbon) and peptone $0.5 \%$ (nitrogen, $\mathrm{w} / \mathrm{v}$ ), respectively. The soluble pollutants were detected by scanning the absorption spectrum in the range of $200-700 \mathrm{~nm}$ at room temperature.

\section{Extraction of residual organic pollutants}

Different organic solvents viz. ethyl acetate, isopropyl alcohol, n-hexane, and methanol were used to know their optimum extractability of remaining residual organic pollutants of the effluent and ethyl acetate was showed maximum solubility for the pollutants ${ }^{21}$. The residual organic pollutants were detected by comparing their mass spectra $(\mathrm{m} / \mathrm{z})$ with the compounds provided in the National Institute of Standards and Technology (NIST) library.

\section{Colony-forming unit (CFU), biomass and total protein}

The total microbial community during the biostimulation process was evaluated with the help of the plate count method (PCA). The sample was serially diluted and about $10 \mu$ of the diluted sample was used as an inoculum to spread over culture plate (Himedia, India). The inoculated plate was incubated overnight at $37^{\circ} \mathrm{C}$ (Chandra et al., 2018) ${ }^{22}$. The biomass estimation, $1 \mathrm{ml}$ of the bacterial growth sample was centrifuged and dry in the pre-weighted eppendorf tube and after dried at $50^{\circ} \mathrm{C}$, the post weight of eppendorf post weight minus the pre weight of eppendorf were estimated to be bacterial biomass per $\mathrm{ml}$. The total extracellular protein of biostimulated sample was estimated using the standard method ${ }^{23}$.

\section{Scanning electron microscopy analysis}

For scanning electron microscopy (SEM) analysis of bacterial community during the biostimulation process, the samples were centrifuged at $6000 \mathrm{rpm}$ for 20 minutes and the supernatant was discarded and pellets were collected. The collected biomass was then fixed and dehydrated using $0.1 \mathrm{M}$ phosphate buffer (pH 7.2) solution and different concentrations of acetone for 20 minutes, respectively ${ }^{24}$. Thereafter, the samples were placed on the aluminium stub and coated with platinum through a sputter coater (SC 7620 Mini Sputter Coater, Quorum Technology Ltd., UK). 


\section{Ligninolytic enzyme assay}

The confirmation of degradation of lignin at different parts per million (ppm) by different ligninolytic enzymes was analysed using different substrates. Based on the oxidation of phenol red and Azure $B$ dye in the presence of $\mathrm{H}_{2} \mathrm{O}_{2}$, the manganese peroxidase $(\mathrm{MnP})$ and lignin peroxidase (LiP) were estimated and the optical density (OD) of both the enzymes was measured at $610 \mathrm{~nm}$ and $651 \mathrm{~nm}$, respectively ${ }^{24}$, ${ }^{25}$. Additionally, the activity of laccase enzyme was estimated by the presence of guaiacol at $450 \mathrm{~nm}$ $\mathrm{OD}$ and further confirmed using plate assay. The $\mathrm{MnP}$, LiP and laccase enzyme assays on the plate were performed as per the standard method ${ }^{24,26}$. Identification of bacterial strains

The potential bacterial strains were isolated and identified as per Cowan and Steels Manual for the identification of medical bacteria ${ }^{27}$. For $16 \mathrm{~S}$ rRNA sequencing, the isolated bacterial strains were overnight incubated in Luria Bertani broth (Himedia Pvt Ltd) and the total DNA was extracted using commercial kit (real Biotech Corporation). The 16S rRNA gene was amplified using universal primers sets16Sf (5' CAGCAGCCGCGGTAATAC 3') and $16 \mathrm{Sr}$ (5' TACGGCTACCTTGTTACG $3^{\prime}$ ). The PCR reaction mixture included assay buffer $5 \mu l$, forward primer $1 \mu \mathrm{l}$, reverse primer $1 \mu \mathrm{l}$, dNTP $1 \mu \mathrm{l}$, template $2 \mu \mathrm{l}$, tag polymerase $1 \mu \mathrm{l}$ and the final total volume was made up $50 \mu \mathrm{l}$ with milli Q water. The reagents were properly mixed and transferred to a thermo cycler (Sure Cycler 8800; Agilent Technologies, Malaysia) under the following thermal cycling conditions, denaturation at $94^{\circ} \mathrm{C}$ for $1 \mathrm{~min}$, followed by annealing at $55^{\circ} \mathrm{C}$ for $1 \mathrm{~min}$ and extension at $72^{\circ} \mathrm{C}$ for $2 \mathrm{~min}$, for 35 repeated cycles. The PCR amplified product of 16S rRNA gene of bacteria was confirmed by agarose gel electrophoresis. Furthermore, the PCR product in the gel was purified using QIA gel extraction kit and processed for sequencing. The sequence data were analysed by BLAST and identified based on closet similarity with the reported sequenced data. A phylogenetic tree was generated using MEGA-6.0 software ${ }^{28}$.

Phytotoxicity evaluation by seed germination test with Triticum aestivum and Cicer arietinum

The phytotoxicity of the effluent with Triticum aestivum and Cicer arietinum was evaluated and analysed as per the guidelines of Organisation for Economic Co-Operation and Development ${ }^{29}$ using the seed germination and root length bioassay tests. After the biostimulation process, a total of the $50 \mathrm{ml}$ sample was collected and centrifuged at $8000 \mathrm{rpm}$ for 20 minutes. The supernatant was collected and filtered using 0.2 $\mu \mathrm{m}$ membranes for the seed germination test. Thereafter, ten seeds each of Triticum aestivum and Cicer arietinum were placed on the three layers of filter papers (Whatman No. 1) kept in a glass petri dish ( $9 \mathrm{~cm}$ in diameter) and moisten with different concentration of the treated and untreated sample.

\section{Statistical Analysis}

All data are presented as means \pm SD for triplicate samples to confirm the data variability and results from validity. All the data were subjected to Statistical analysis Tukey's test ${ }^{30}$ (Ott, 1984) using the Graph Pad software (Graph Pad Software, San Diego, CA).

\section{RESULTS AND DISCUSSION}

\section{Physico-chemical parameter}

The physico-chemical analysis of effluent had higher values of $\mathrm{pH}\left(8.6 \mathrm{mg} \mathrm{L}^{-1}\right), \mathrm{TS}(742 \mathrm{mg}$ $\left.\mathrm{L}^{-1}\right)$, TDS (549 $\left.\mathrm{mg} \mathrm{L}^{-1}\right)$, TSS (59 $\left.\mathrm{mg} \mathrm{L}^{-1}\right)$, COD (20349 $\mathrm{mg} \mathrm{L}^{-1}$ ), BOD (25946 $\mathrm{mg} \mathrm{L}^{-1}$ ), was compared to treated sample (Table 1). The alkaline $\mathrm{pH}$ might be due to the presence of residual content of sodium hydroxide and sodium sulfide utilized in pulping process of the industry ${ }^{31}$. The five days BOD/COD of the effluent were 0.21 and 0.20 , respectively suggesting the decreased degradability of pollutants present in the discharged effluent. The increase in TDS value might be due to the presence of dissolved lignocellulosic particles along with fine fibres plus pith particles and adequate concentration of $\mathrm{Na}^{+}$and $\mathrm{K}^{+}$which all together contribute to the salinity of effluent. The higher EC value might be due to increase in salt and ions content of effluent. Moreover, lignin and chlorophenols contents were noted to be very high in effluent which might be the source of the dark color. The dark color adversely affected aquatic flora and fauna. Consequently, it causes aquatic toxicity and soil pollution ${ }^{32}$. The high concentrations of total phenols ( $\left.421 \mathrm{mg} \mathrm{L}^{-1}\right)$, total nitrogen (156 $\left.\mathrm{mg} \mathrm{L}^{-1}\right)$, sulphate $(1854 \mathrm{mg}$ $\left.\mathrm{L}^{-1}\right)$, phosphorus (176 mg L-1), chloride $(2.01 \mathrm{mg}$ 
Table 1. Physico-chemical characteristics of pulp paper mill effluent and their heavy metals content. All the values

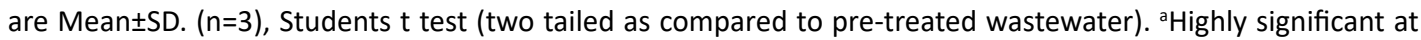
$p<0.001$, 'bignificant at $p<0.01$, 'Less significant at $p<0.05$, Ns Non-significant at $p>0.05$

\begin{tabular}{llll}
\hline Parameters & $\begin{array}{l}\text { Effluent values before } \\
\text { bioremediation (Mean } \pm \text { SD) }\end{array}$ & $\begin{array}{l}\text { Effluent values after } \\
\text { bioremediation }\end{array}$ & $\begin{array}{l}\text { Permissible limit } \\
\text { (EPA 2002) }\end{array}$ \\
\hline pH & $8.6 \pm 0.03$ & $6.9 \pm 0.17^{\mathrm{a}}$ & $5-9$ \\
TS & $742 \pm 110$ & $222 \pm 12^{\mathrm{b}}$ & - \\
TDS & $549 \pm 12.34$ & $127 \pm 7.54^{\mathrm{b}}$ & - \\
TSS & $59 \pm 2.01$ & $20.33 \pm 2.08^{\mathrm{c}}$ & 35 \\
COD & $20349 \pm 205.00$ & $3452 \pm 50.21^{\mathrm{a}}$ & 120 \\
BOD & $25946 \pm 120$ & $6248 \pm 531^{\mathrm{a}}$ & 40 \\
Total phenols & $421 \pm 11.34$ & $346.33 \pm 28.72^{\mathrm{c}}$ & 0.50 \\
Total nitrogen & $156 \pm 5.34$ & $201.66 \pm 21.03^{\mathrm{c}}$ & 143 \\
Sulphate & $1854 \pm 11.70$ & $1311 \pm 47^{\mathrm{a}}$ & 250 \\
Phosphorus & $176 \pm 7.20$ & $156 \pm 6.45^{\mathrm{b}}$ & 180 \\
$\mathrm{Cl}-$ & $2.01 \pm 0.00$ & $1.36 \pm 0.12^{\mathrm{c}}$ & 1500 \\
$\mathrm{Na}+$ & $75 \pm 19.90$ & $23.33 \pm 3.05^{\mathrm{c}}$ & 200 \\
$\mathrm{~K}+$ & $8.4 \pm 0.20$ & $1.731 \pm 0.25^{\mathrm{c}}$ & - \\
Lignin & $47568 \pm 13.20$ & $1628 \pm 75^{\mathrm{b}}$ & 0.05 \\
Chlorophenol & $201 \pm 21.00$ & $183 \pm 20.66^{\mathrm{c}}$ & 3.0 \\
$\mathrm{Heavy}$ metals (mg L-1) & & & \\
Fe & $75.23 \pm 1.00$ & $1.89 \pm 0.10^{\mathrm{b}}$ & 2.00 \\
$\mathrm{Zn}$ & $15.60 \pm 0.30$ & $0.95 \pm 0.17^{\mathrm{c}}$ & 2.00 \\
Cu & $4.1 \pm 0.05$ & $0.32 \pm 0.09^{\mathrm{NS}}$ & 0.50 \\
$\mathrm{Cr}$ & $3.12 \pm 0.05$ & $0.61 \pm 0.11^{\mathrm{c}}$ & 0.05 \\
Cd & $0.324 \pm 0.01$ & $0.05 \pm 0.02^{\mathrm{NS}}$ & 0.01 \\
$\mathrm{Mn}$ & $13.24 \pm 0.00$ & $0.55 \pm 0.09^{\mathrm{c}}$ & 0.20 \\
$\mathrm{Ni}$ & $4.01 \pm 0.01$ & $0.33 \pm 0.07^{\mathrm{c}}$ & 0.10 \\
\hline
\end{tabular}

$\left.\mathrm{L}^{-1}\right)$, sodium (75 $\left.\mathrm{mg} \mathrm{L}^{-1}\right)$, and potassium (8.4 mg $\left.\mathrm{L}^{-1}\right)$, were present in effluents which were above the permissible limit (Table 1). High concentration of chloride in the effluent generally causes more toxicity than sulphate to aquatic flora and fauna including microbial community. Furthermore, a significant amounts of $\mathrm{Fe}\left(75.23 \mathrm{mg} \mathrm{L}^{-1}\right), \mathrm{Zn}$ (15.60 $\left.\mathrm{mg} \mathrm{L}^{-1}\right), \mathrm{Cu}\left(4.1 \mathrm{mg} \mathrm{L}^{-1}\right), \mathrm{Cr}\left(3.12 \mathrm{mg} \mathrm{L}^{-1}\right)$, $\mathrm{Cd}\left(0.324-\mathrm{mg} \mathrm{L}^{-1}\right), \mathrm{Mn}\left(13.24 \mathrm{mg} \mathrm{L}^{-1}\right)$ and $\mathrm{Ni}$ (4.01 $\mathrm{mg} \mathrm{L}^{-1}$ ), were present in effluent which are hazardous to the environment. Thus, the pulp paper industry effluent are rendered unfit for irrigation and drinking purpose due to its adverse effect on the respiratory system, alimentary canal, nervous system, coronary system and reproductive system in the aquatic organism ${ }^{33}$. A similar observation was reported by earlier findings ${ }^{34,13}$. The source of heavy metals in effluent might be due to the alkaline black liquor corrosion activity produced during digestion of wood and inefficient utilization of the organic contents by the bacterial communities in treatment plant.

\section{UV-Vis spectroscopy analysis of effluent}

The degradability of effluent after biostimulation process was confirmed by UVVis scanning absorption spectrum and showed elevation in overall along with generated scan peaks (Fig.1a-b). Results revealed comparative absorption spectrum by UV-Vis spectroscopy for control and degraded sample between 250 to 700 $\mathrm{nm}$. Moreover, disappearances of some peaks in degraded sample and decreasing of absorption maxima indicated depolymerisation of organic compounds present in effluent. Similarly, the comparison of control and degraded sample at similar pattern of these data has been also recorded in our previous study for degradation of ligninocellulogic compound present in pulp and paper industry waste ${ }^{16}$. The result revealed a high peak absorption in different UV-region with 
maximum absorbance $\left(\lambda_{\max }\right)$ of $\lambda_{\max } 250, \lambda_{\max } 270$ and $\lambda_{\max } 310$ before biostimulation in effluent as control showed in Fig.1a-b. Moreover, after biostimulation the new peaks with maximum absorbance of $\lambda_{\max } 270, \lambda_{\max } 310$ and $\lambda_{\max } 370$ were noted while some peak disappeared as shown in Fig. 1b. This change in the peak area and height indicates the conversation of compounds into complex metabolites ${ }^{22}$.

\section{Evaluation of remediation of organic pollutants}

The characterisation and identification of residual organic pollutants was done by GCMS analysis from pulp paper industry effluent discharged after secondary treatment. The evaluation of degraded organic pollutants before and after biostimulation process revealed the change in peak height and retention time (RT) (Fig.2a-b and Table 2). The major pollutants were identified at RT-10.36, RT-10.59, RT-15.10, RT17.82, RT-22.94, RT-25.25, RT-25.54 and RT-25.47 which are listed in Table 2. Out of these compounds, some were with EDCs nature compound identified as hexadecanoic acid, trimethylsilyl ester (RT22.94) and pentadecanoic acid (RT-25.54) and were reported as mutagenic compound by United States Environmental Protection Agency ${ }^{35}$ and Endocrine Disruptor Screening Program ${ }^{36}$. The persistent organic contaminants were also extracted with similar conditions of control after degradation by biostimulation process. In addition, tetradecanoic acid and hexadecanoic acid are essential plant-based fatty acids in humic substances $^{45}$. RT-10-59 was detected as benzoic acid from effluent sample and it will be reduced during biostimulation process by potential bacterial strains. Moreover, cinnamic acids (RT18.58) were detected in biostimulated extracted sample, which is known as the product of lignin and hemicellulose fraction of lignocellulose. Cinnamic acid and guaiacol are thought to be generated in the lignin polymer by cleavage of ester linkages in guaiacyl and p-hydroxyphenyl units $^{37}$. They are also capable to form ester and ether linkages via reaction of their carboxyl and phenolic groups, respectively ${ }^{38}$. Most of the ester bonds are destroyed during the alkaline extraction of the pulping process, but some cinnamic acid remain bound to the lignin by ether, which were degraded during biostimulation process. Several saturated fatty acids such as octadecanoic acid (RT-30.37) and trimethylsilyl ester were also found in effluent (control sample) and degraded finally by bacterial community after biostimulation process. This study is supported by the previous research of degradation and detoxification of effluent ${ }^{22}$. Moreover, octadecanoic acid was detected from Eucalyptus camaldulensis and is also reported as extractive of ethanol or benzene ${ }^{39}$. All the above compounds have a methoxyphenol group in their structures, but at the position opposite to the hydroxyl group on the aromatic ring. Moreover, the majority of these compounds are monomers of lignin compounds. Most of these compounds are disappeared after biostimulation process. Among these compounds, octadecanoic, hexadecanoic and lactic acid are predominated

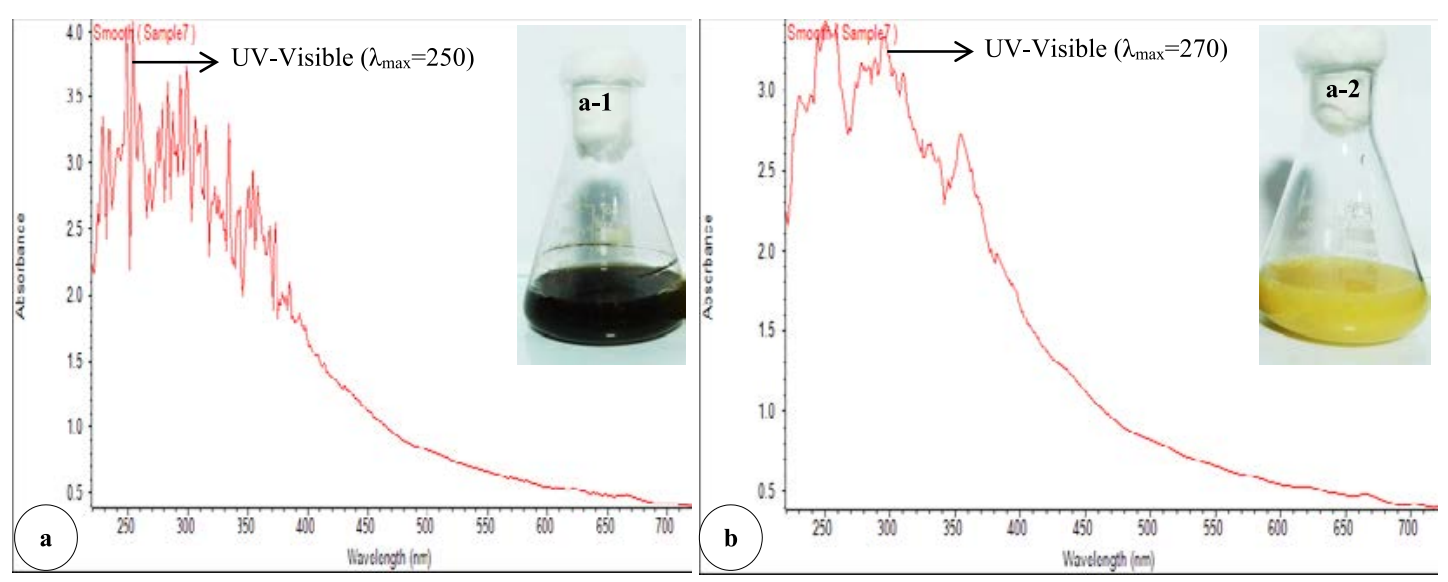

Fig. 1. UV-Vis spectroscopy analysis for investigate the degradability of pollutants at $250-700 \mathrm{~nm}$ before and after biostimulation process (a.a-1). Effluent before biostimulation process (b. b-2). Effluent after biostimulation process. 
Table 2. Identified residual organic pollutants by GC-MS analysis in the TMS derivatized ethyl acetate extracts of pulp paper industry effluent

\begin{tabular}{|c|c|c|}
\hline Retention Time (RT) & Identified compounds & Toxicity \\
\hline \multicolumn{3}{|c|}{ Before Bioremediation } \\
\hline 6.88 & 2-Butoxyethanol & Acute toxicity \\
\hline 10.10 & 9-decenoic acid, trimethylsilyl ester & Data not reported \\
\hline 10.36 & D-Lactic acid-DITMS & Acidosis \\
\hline 10.59 & Benzoic acid, Trimethylsilyl ester & $\begin{array}{l}\text { Gastric pain, vomiting, and allergic } \\
\text { reactions }\end{array}$ \\
\hline 15.10 & 2,3,6-trimethyl phenol & Unknown \\
\hline 17.82 & Citral & Reproductive toxicity \\
\hline 18.58 & Cinnamic acid & Eco toxicity \\
\hline 22.94 & $\begin{array}{l}\text { Hexadecanoic acid, trimethylsilyl } \\
\text { ester (Palmitic acid) }\end{array}$ & $\begin{array}{l}\text { Endocrine disrupting chemicals } \\
\text { (EDCs) }\end{array}$ \\
\hline 25.25 & $\begin{array}{l}\text { 2',6'-Dihydroxyacetophenone, } \\
\text { bis(trimethylsilyl) ether }\end{array}$ & Data not reported \\
\hline 25.54 & Pentadecanoic acid & EDCs \\
\hline 27.47 & Phenol-4-ethyl-2-methoxy or 4-Ethylguaiacol & Data not reported \\
\hline 30.37 & Octadecanoic acid, trimethylsilyl ester & EDCs \\
\hline 48.67 & Phenol,2,6-dimethoxy or syringols & Aquatic toxicity \\
\hline 49.98 & Pthalatic anhydride & Data not reported \\
\hline \multicolumn{3}{|c|}{ After Bioremediation } \\
\hline 22.41 & $\begin{array}{l}\text { Phenol-2-methoxy-4-(1-propenyl } \\
\text { or isoeugenol) }\end{array}$ & Data not reported \\
\hline 32.27 & 1,2-benzendicarboxylic acid disononyl ester & Data not reported \\
\hline 33.29 & $\begin{array}{l}\text { Benzyldehyde,4-(acetyloxy)-3-methoxy or } \\
\text { acetyl vanillin }\end{array}$ & Data not reported \\
\hline 35.80 & 2,6-bis[trimethylsilyl]-3,4-dimethylphosphinine & Unknown \\
\hline 51.19 & $\begin{array}{l}\text { 1,2-benzenedicarboxylic acid,bis } \\
\text { (2-ethylhexyl)ester }\end{array}$ & Unknown \\
\hline 53.69 & $\begin{array}{l}\text { 5,8-dimethoxy-6-methyl-2,4-bis(phenyl methyl) } \\
\text { naphthalene }\end{array}$ & Data not reported \\
\hline 55.77 & $\begin{array}{l}\text { 9-[2,6-diethylphenyl]2,8-dimethyl-9-h- } \\
\text { purin-6-amine }\end{array}$ & Unknown \\
\hline
\end{tabular}

most in effluent ${ }^{40}$. The toxicity of hexadecanoic acid is reported as an endocrine-disrupting chemical which is responsible for the hormonal disorder in fishes.

\section{CFU, protein and biomass production}

The measurements of CFU and biomass during the biostimulation process revealed continuous increase in comparison to the control (Fig. 3). The enhanced microbial community was observed after the addition of nutrients at different environmental conditions. The reduction of color was also observed in comparison to control, attributed to reduction of lignin and its metabolite during biostimulation process. The increase in biomass and CFU after enhancement of the carbon and nitrogen supply showed that the autochthonous microbial communities do not have sufficient organic compounds present in the effluent as a nutrient. Hence, increase in the biomass could only be possible after addition of nutrients. The biomass increases the assisted biostimulation process. The gradual increase in the bacterial cell with diversified morphology also shows a strong confirmation of detoxification of effluent after biostimulation process. Further, it confirmed that in the presence of optimum nutrient and environmental conditions, the increasing bacterial community has sufficient potential for degradation of residual complex organic compounds. The degradation and detoxification of complex organic compounds from anaerobically digested effluent distillery 


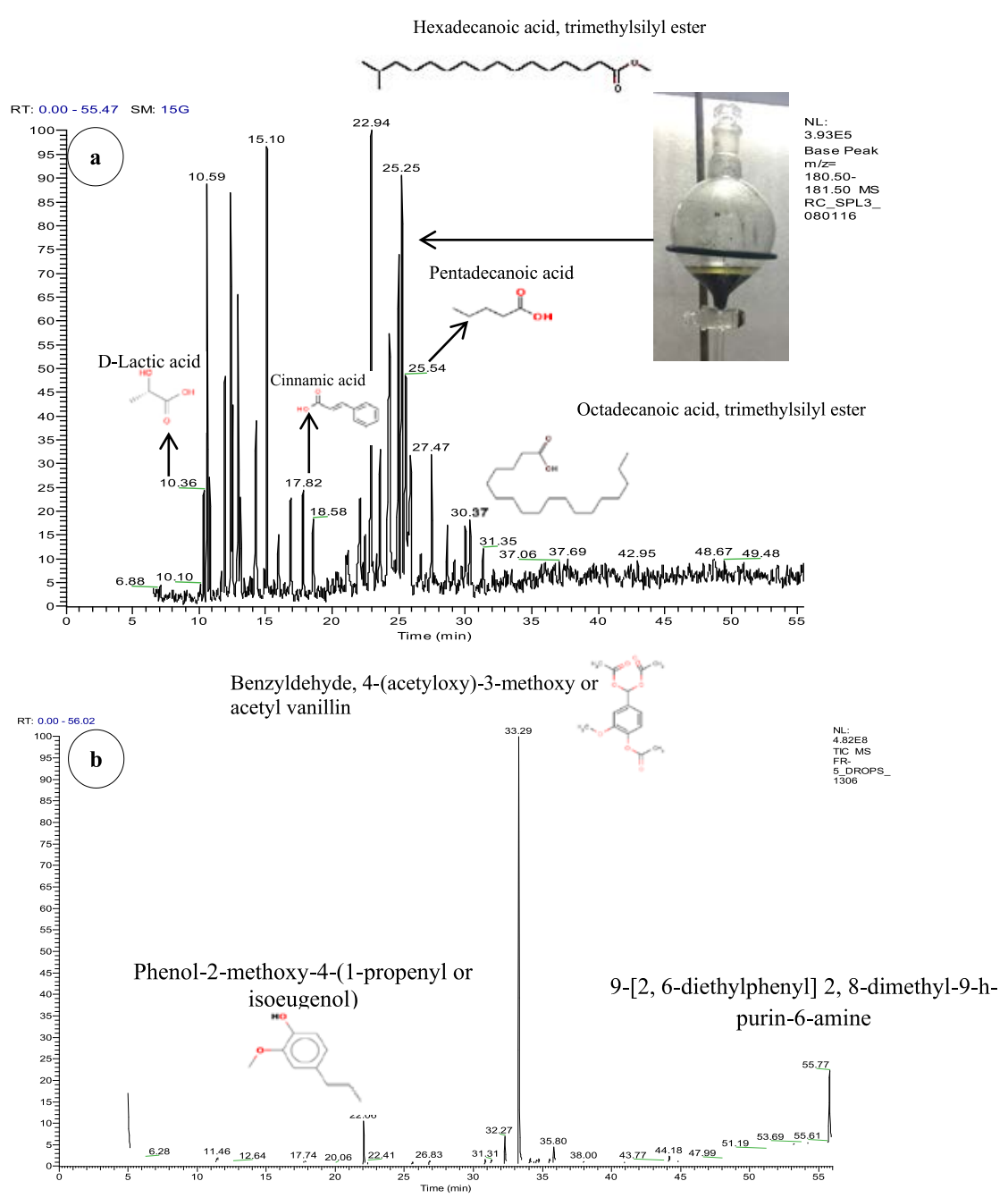

Fig. 2. Total lon chromatogram (TIC) of TMS derivatized detected residual organic pollutants from wastewater by ethyl acetate extract of biostimulation process (a). Effluent before the biostimulation process (b). Effluent after the biostimulation process.

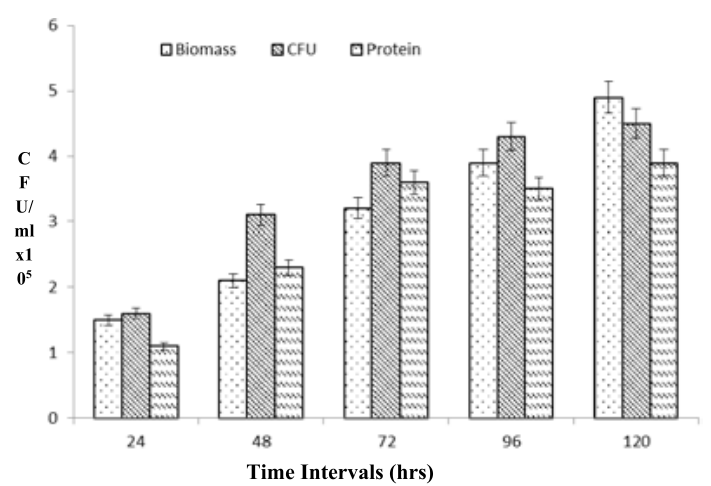

Fig. 3. Pattern of biomass, colony forming unit and protein contents in the pulp paper industry effluent after biostimulation process. was observed after supplementing adequate nutrients ${ }^{24}$.

Morphological view of bacterial community during biostimulation

The SEM analysis of the biostimulated sample showed the diversity of bacterial community (Fig. 4a-b). Besides, there was also a reduction in color, lignin, and organic compounds compared to control over the bacterial growth period. Addition of nutrient increases the bacterial community. Furthermore, SEM analysis of degrading samples also supported the evidence that the organic compounds are utilized as nutrients through the process of co-metabolism for cell multiplication. The significant increase in 

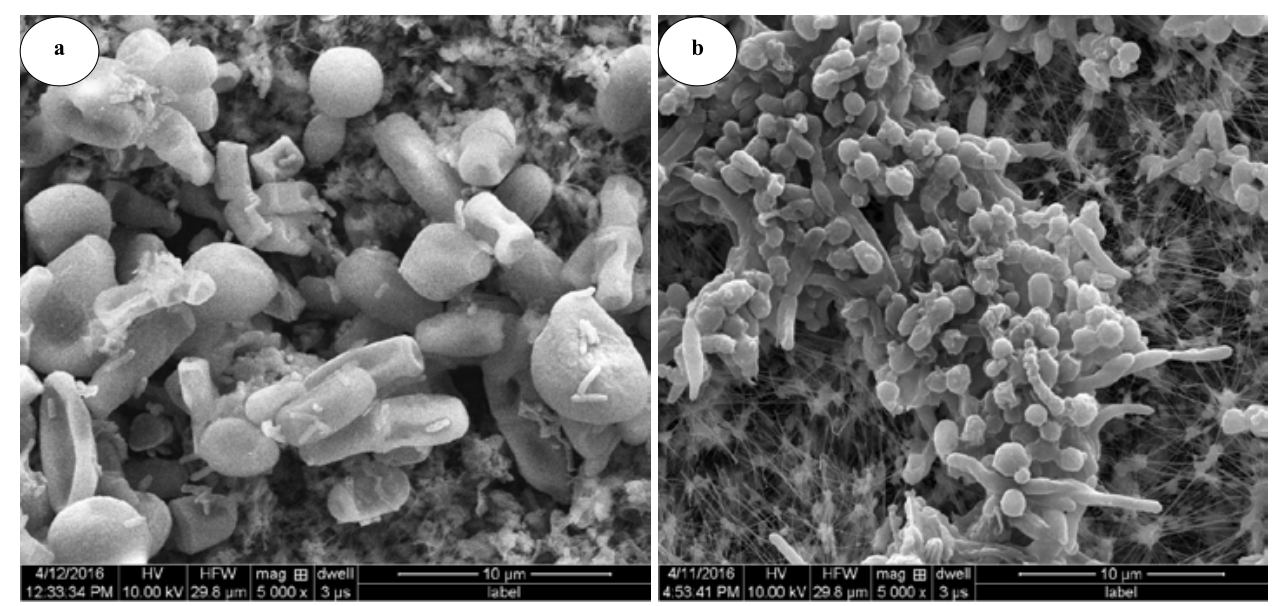

Fig. 4. Morphological view of bacterial strains observed under scanning electron microscopy analysis during bioaugumentation process at 5000x magnification (a-b).

the bacterial cells with diversified morphology strongly indicated that the bacterial species are essential for detoxification of different pollutants found in the effluent. The result revealed complex irregular structure mixed with an elongated rod or cylindrical shaped bodies and organic polymer i.e.

lignin, cellulose and heterogeneous compound on the surface of effluent. A similar observation for the granulated appearance of lignin with the complete structure of different size has been reported in an earlier stud $\mathrm{y}^{41}$. Furthermore, the irregular shape is also indicating the lignin complexion with different
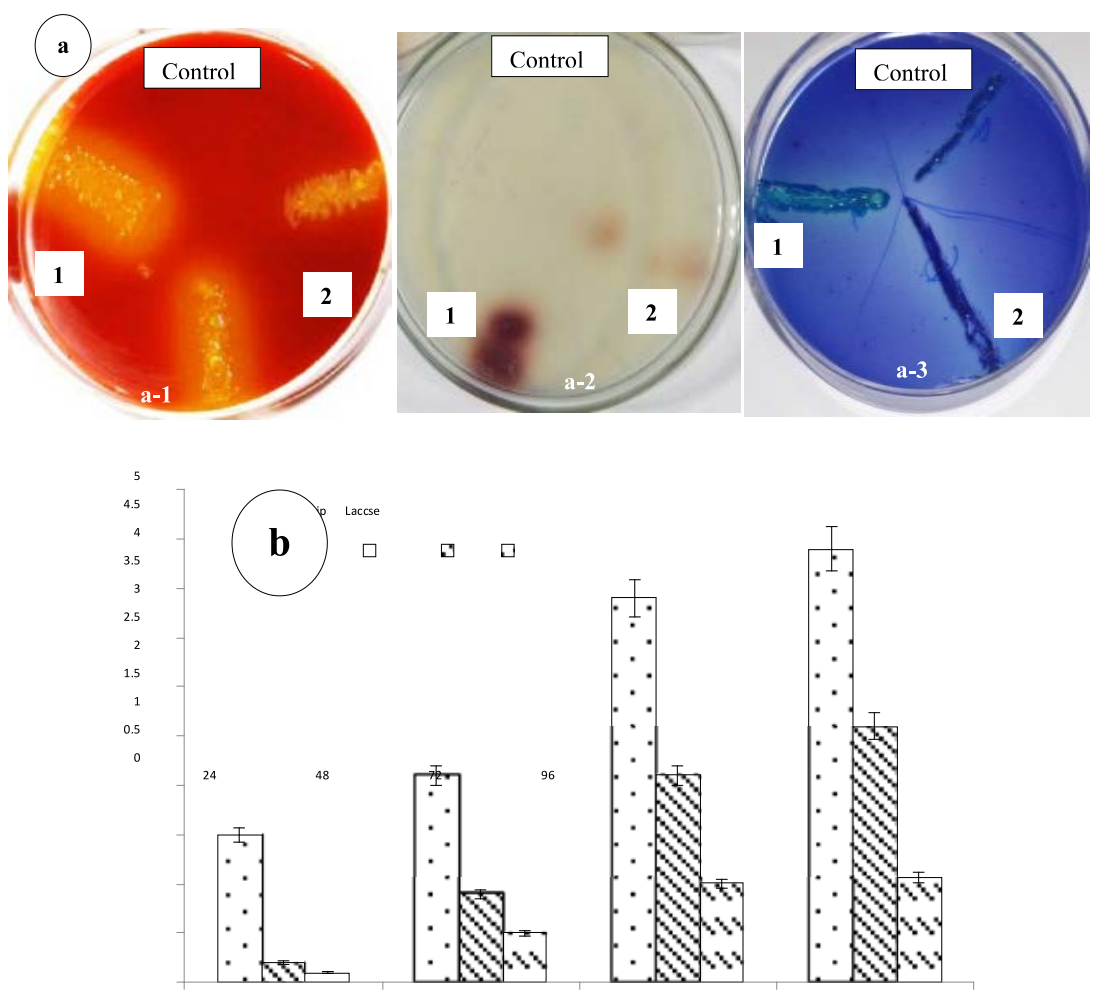

Fig. 5. The ligninolytic i.e. a-1 (Mnp), a-2 (Lip) and a-3 (Laccase) enzyme activity isolated bacterial strains a (Aeromonas salmonicida) and $\mathrm{b}$ (Bacillus $\mathrm{sp}$ ) on plate assay ( $\mathrm{a}$ ) and for the extracellular enzyme activity was measure by biostimulated sample (b). 
heavy metals and another carbonyl, hydroxyl and phenolic compounds ${ }^{42}$.

\section{Ligninolytic enzyme activity}

The role of extracellular enzyme activity by the bacterial community during the biostimulation is shown in Fig. 5 . The maximum $\mathrm{MnP}$ was noted as $520 \mathrm{U} / \mathrm{ml}$ between $90-92 \mathrm{~h}$ of the biostimulation process. The Lip and MnP were recorded as dominating enzymes at the initial stage of bacterial growth during the biostimulation process. The highest Lip was recorded as 0.0079 and $0.0091 \mathrm{U} / \mathrm{ml}$, respectively at 48 and $96 \mathrm{~h}$ of incubation during bacterial growth in order to degrade organic pollutants. However, the incubation of laccase at the later stage of growth phase i.e. at $120 \mathrm{~h}$ indicated that phenolic compound was dominant and laccase could contribute very vital role. Moreover, maximum induction of laccase $(41.0 \mathrm{U} / \mathrm{ml})$ was noted at 120 $h$. The role of extracellular enzyme activity by the autochthonous bacterial community was observed during the degradation of effluent. The enzymes secreted by bacteria during the biostimulation process were measured in the supernatant after centrifugation of sample. Moreover, Lip and MnP were recorded as dominating enzymes at the initial stage of bacterial growth. The observation of ligninolytic enzyme activity was observed on plate assay based on the selective agar qualitative screening and different indicator dye (Fig.6). The strong zone across the bacterial colony indicates the production of ligninolytic enzymes on the phenol red plate by the potentially isolated Mnp on phenol red plate, laccase on the guaiacol plate and Lip on the azure-B plate (Fig.5a-1, a-2, a-3). The ability to produce Mnp enzymes of isolated bacterial strains (Aeromonas salmonicida and Bacillus sp.) was measured by comparing the diameter of the colony and yellow-brown circles. Moreover, laccase is a multicopper oxidase and forms a brown zone due to the presence of guaiacol by the single-electron oxidation of organic compounds for the respective radical species. The bacterial cell produces extracellular oxidative enzymes including peroxidases that have been involved in lignin degradation. The combination of

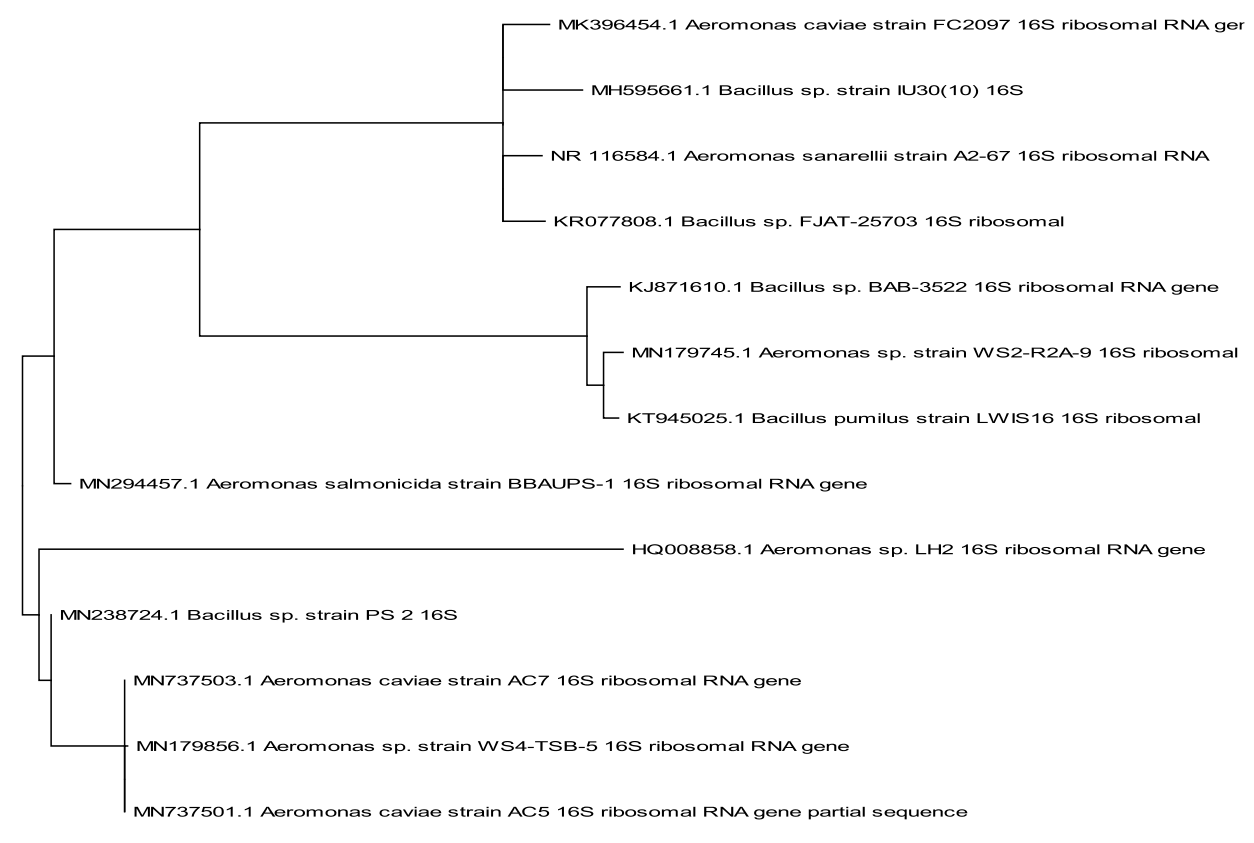

Fig. 6. Phylogenetic tree showing the relationship of bacterial communities growing during biostimulation process. The accession numbers for all strains used in tree construction are indicated in the figure. 
these extracellular peroxidases has applications in the removal of phenolic compounds from effluent along with lignin degradation ${ }^{43}$.

Purified isolated bacterial strains were identified based on $16 \mathrm{~S}$ rRNA sequencing. The $16 \mathrm{~S}$ rRNA sequence data were submitted to National Center for Biotechnology Information Search database (NCBI) using the Basic Local Alignment Search Tool (BLAST) tool and the obtained sequences were then further compared with sequences of bacteria from known taxa. Further strains BBAUPS-1 (Aeromonas salmonicida) and BBAUPS-2 (Bacillus sp.) were isolated based on $16 \mathrm{~S}$ rRNA sequencing. Moreover, the partial sequences were submitted to the GenBank public database under the accession number MN294457.1 (BBAUPS-1) and MN238724 (BBAUPS-2), respectively (Fig.6).

Phytotoxicity evaluation after biostimulation process

The seed germination test of Triticum aestivum and Cicer arietinum was inhibited most by 88 and $96 \%$ after irrigation with effluent from the pulp paper industry site in comparison to the control samples in which it is least inhibited i.e. 8 and $9 \%$, respectively (Fig.7a-b). The comparative
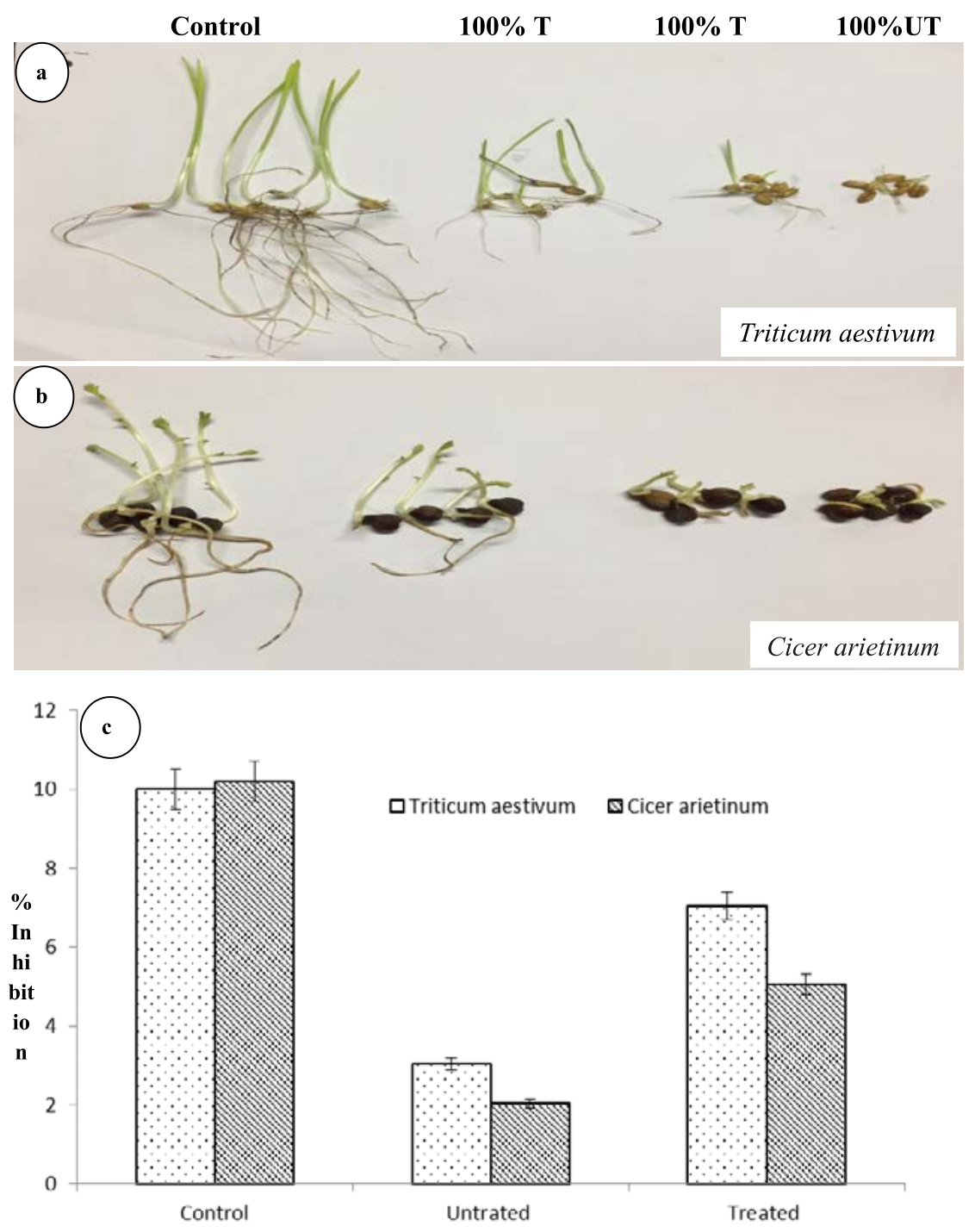

Fig. 7. Seed germination test by effluent of pulp paper industry untreated and bacterial treated on Triticum aestivum (a) Cicer arietinum (b) percent inhibition of seed germination (c), T-treated, UT-untreated 
toxicity assessment of biostimulated samples revealed reduction in the toxicity of effluent and increase in the growth of plants. Further, the result also revealed that Cicer arietinum was found more sensitive than Triticum aestivum (Fig.7.c). The increased toxicity in seed germination was observed due to the presence of metals and ions in the effluent in high concentration in the control sample. The comparative cytotoxic and genotoxicity effect of effluent before and after biostimulated sample on A. cepa roots were also determined based on chromosomal aberrations ${ }^{44}$. Reducing effluent toxicity has supported the removal of pollutants after the bacterial growth on toxic compounds. The seed germination tests showed inhibition in the seed germination attributed to the toxic compounds which were inhibitory for the $\alpha$-amylase enzyme. Similar observations were also reported in earlier studies $^{24}$. The inhibitions shown in this assessment were underdeveloped root length and the lateral root due to some hormonal disturbance in the treated plant. These results clearly indicated that the increase in the toxicity of effluent was directly related to the load of pollutants.

\section{CONCLUSION}

Thestudyconcludes that the biostimulation process is suitable for the optimization of degradation and decolorization of the pulp paper industry effluent after secondary treatment. The effluent contains various organic and inorganic pollutants along with high concentration of ion and salts that cause phytotoxicity in Triticum aestivum and Cicer arietinum. The discharged effluent is reported as the main source of soil and aquatic pollution in the large area of agricultural land. These effluents have inhibitory effects over seed germination and in turn reduce the productivity of land and subsequently reduce farmer's income. The biostimulation process enhances the remediation strategy of residual organic pollutants by the bacterial community and is suitable for detoxification and decolorization of effluent for safe environmental disposal. In addition, disposal of effluent after such treatment and processes will not harm the environment much and provide better support to the agricultural system of India.

\section{ACKNOWLEDGMENTS}

Authors would like to thank Babasaheb Bhimrao Ambedkar (Central) University and Prof. (Dr.) Ram Chandra for providing the facilities to undertake this research work. The authors thank the CSIR-Indian Institute of Toxicology Research (IITR) Lucknow, for Instrumentation facilities of Scanning Electron Microscopy.

\section{CONFLICT OF INTEREST}

The authors declare that there is no conflict of interest.

\section{AUTHORS' CONTRIBUTION}

This work is done by PS as PhD Scholar, while bacterial sequencing was done by $\mathrm{PC}$ and Deepshi Chaurasia. ST has supported to draft this manuscript and Prof. Ram Chandra has worked as overall mentor of the work.

\section{ETHICS STATEMENT}

This article does not contain any studies with human participants or animals performed by any of the authors.

\section{FUNDING}

This work is supported by Department of Biotechnology (DBT), New Delhi, India vide letter no. BT/PR18896/BCE/8/1372/2016 Dated 28.3.2018 Govt. of India New Delhi.

\section{DATA AVAILABILITY}

All datasets generated during this study are included in the manuscript and the Supplementary Files.

\section{REFERENCES}

1. Pokhrel D, T. Viraraghavan, Treatment of pulp and paper mill wastewater-a review. Sci Total Environ. 2004;333:37-58. https://doi.org/10.1016/j. scitotenv.2004.05.017

2. Ugurlu M, Gurses A, Dogar C, M Yalcin. The removal of lignin and phenol from paper mill effluents by electrocoagulation. J Environ Manage. 2007;87:420428. https://doi.org/10.1016/j.jenvman.2007.01.007

3. Latorre A, Rigol A, Lacorte S, D Barcelo. Organic compounds in paper mill wastewaters. In: Hutzinger O (ed) The handbook of environmental chemistry. Springer, Berlin. 2005;19:25-51. https://doi. org/10.1007/b98606

4. Ratia $H$, Ramanen $H$, Lensu A, A Oikari. Betulinol and wood sterols in sediments contaminated by 
pulp and paper mill effluents: dissolution and spatial distribution. Environmental Science Pollution Research. 2013;20:4562-4573. https://doi.org/10.1007/s11356012-1381-3

5. Ratia H, Vuori KM, A Oikari. Caddis larvae (Trichoptera, Hydropsychidae) indicate delaying recovery of a watercourse polluted by pulp and paper industry. Ecological Indicator. 2012;15:217-226. https://doi. org/10.1016/j.ecolind.2011.09.015

6. Merilainen P, A Oikari. Uptake of organic xenobiotics by benthic invertebrates from sediment contaminated by the pulp and paper industry. Water Research. 2008;42:1715-1725. https://doi.org/10.1016/j. watres.2007.10.028

7. Hynynen J, Palomaki A, Merilainen JJ, Witick A, K Mantykoski. Pollution history and recovery of a boreal lake exposed to a heavy bleached pulping effluent load. Journal of Paleolimnology. 2004;32:351-374. https:// doi.org/10.1007/s10933-004-0266-y

8. Orrego RI, Guchard J, Hernandez V, et al. Pulp and paper mill effluent treatments have differential endocrine-disrupting effects on rainbow trout. Environ Toxicol Chem. 2009;28:181-188. https://doi. org/10.1897/08-191.1

9. Kaplan CW, CK Kitts. Bacterial succession in a petroleum land treatment unit. App Environ Microbiol. 2004;70:777-1786. https://doi.org/10.1128AEM.70.3. 1777-1786.2004

10. Alharbi OM, Khattab RA, I Ali. Health and environmental effects of persistent organic pollutants. Journal of Molecular Liquids. 2018;263,442-453. https://doi. org/10.1016/j.molliq.2018.05.029

11. AA Basheer. New generation nano-adsorbents for the removal of emerging contaminants in water. Journal of Molecular Liquids. 2018;261:583-593. https://doi. org/10.1016/j.molliq.2018.04.021

12. Abd-Elsalam HE, AA El-Hanafy. Lignin biodegradation with Ligninolytic bacterial strain and comparison of Bacillus subtilis and Bacillus sp. isolated from Egyptian soil. American-Eurasian J Agricul Environ Sci. 2009;5:39-44.

13. Madan S, Sachan P, U Singh. A review on bioremediation of pulp and paper mill effluent "An alternative to conventional remedial technologies. Journal of Applied and Natural Science, 2018;10:367-374. https://doi. org/10.31018/jans.v10i1.1632

14. Ali I, Gupta VK, HY Aboul-Enein. Metal ion speciation and capillary electrophoresis: Application in the new millennium. Electrophoresis. 2005;26:3988-4002. https://doi.org/10.1002/elps.200500216

15. Burakova EA, Dyachkova TP, Rukhov AV, et al. Novel and economic method of carbon nanotubes synthesis on a nickel magnesium oxide catalyst using microwave radiation. Journal of Molecular Liquids. 2018;253:340346. https://doi.org/10.1016/j.molliq.2018.01.062

16. Chandra R, R Singh. Decolourization and detoxification of rayon grade pulp paper mill effluent by mixed bacterial culture isolated from pulp paper mill effluent polluted site. Biochemical Engineering Journal. 2012;61:49-58. https://doi.org/10.1016/j. bej.2011.12.004

17. Chandra R, Raj A, Purohit HJ, A Kapley. Characterisation and optimisation of three potential aerobic bacterial strains for kraft lignin degradation from pulp paper waste. Chemosphere. 2007;67:839-846. https://doi. org/10.1016/j.chemosphere.2006.10.011

18. Ali I, Asim M, TA Khan. Arsenite removal from water by electro-coagulation on zinc-zinc and copper-copper electrodes. Int J Sci Environ Technol. 2013;10:377-384. https://doi.org/10.1007/s13762-012-0113-z

19. Ali I, Alharbi OM, Alothman ZA, Badjah AY, A Alwarthan. Artificial neural network modelling of amido black dye sorption on iron composite nano material: kinetics and thermodynamics studies. Journal of Molecular Liquids. 2017;250:1-8. https://doi.org/10.1016/j. molliq.2017.11.163

20. American Public Health Association. Standard Method for Examination of Water and Wastewater, $22^{\text {nd }}$ edn. Washington, DC: APHA, 2012.

21. Chandra R, Bharagava RN, Yadav S, D Mohan. Accumulation and distribution of toxic metals in wheat (Triticum aestivum L.) and Indian mustard (Brassica campestris L.) irrigated with distillery and tannery effluents. J Hazard Mater. 2009;162:1514-1521. https://doi.org/10.1016/j.jhazmat.2008.06.040

22. Chandra R, Sharma P, YadavS, STripathi. Biodegradation of Endocrine-Disrupting Chemicals and Residual Organic Pollutants of Pulp Paper Mill Effluent by Biostimulation. Front Microbiol. 2018;9:1-15. https:// doi.org/10.3389/fmicb.2018.00960

23. Lowry OH, Rosebrough NJ, Farr AL, RJ Randall. Protein measurement with the folin phenol reagent. Journal of Biological Chemistry. 1951;193:265-275.

24. Sangeeta Y, Chandra R, R Vibhuti. Characterization of potential MnP producing bacteria and its metabolic products during decolourisation of synthetic melanoidins due to biostimulatory effect of $d$-xylose at stationary phase. Process Biochemistry. 2011;46:17741784. https://doi.org/10.1016/j.procbio.2011.05.026

25. Oliveira PLD, Duarte MCT, Ponezi AN, LR Durrant. Purification and partial characterization of manganese peroxidase from Bacillus pumilus and, Paenibacillus sp. Braz J Microbiol. 2009;40:818-826. https://doi. org/10.1590/S1517-83822009000400012

26. Arora DS, Chander M, PK Gill. Involvement of lignin peroxidase, manganese peroxidase and laccase in degradation and selective ligninolysis of wheat straw. Int Biodeter Biodegradation. 2002;50:115-120. https:// doi.org/10.1016/S0964-8305(02)00064-1

27. Barrow GI, Feltham RKA. Cowan Steels Manual for the identification of medical bacteria. Third ed. Cambridge University Press, Great Britain. 1993; https://doi. org/10.1017/CBO9780511527104

28. Tamura K, Stecher G, Peterson D, Filipski A, S Kumar. MEGA6: molecular evolutionary genetics analysis version 6.0. Molecular Biology and Evolution. 2013;30:2725-2729. https://doi. org $/ 10.1093 / \mathrm{molbev} / \mathrm{mst} 197$

29. OECD, Guideline for testing of chemicals. Terrestrial plant tests: 208: Seedling emergence and seedling growth test, 1-19. 2003.

30. Ott L. An introduction to statistical methods and data analysis. 2nd ed. Boston, MA: PWS.1984. https://doi. org/10.2307/1269399 
31. Yadav S, R, Chandra. Detection and assessment of the Phytotoxicity of residual organic pollutants in sediment contaminated with pulp and paper mill effluent. Environmental Monitoring Assessment. 2018;190:581591. https://doi.org/10.1007/s10661-018-6947-1

32. Wu G, Guan Y, X Zhan. Effect of salinity on the activity, settling and microbial community of activated sludge in sequencing batch reactors treating synthetic saline wastewater. Water Sci Technol. 2008;58:351-357. https://doi.org/10.2166/wst.2008.675

33. Reddy PM, NS Rao. Effects of Industrial Effluents on the Groundwater Regime in Visakhapatnam. Pollution Research. 2001;20:383-386.

34. Chandra R, A Abhishek. Bacterial decolorization of black liquor in axenic and mixed condition and characterization of metabolites. Biodegradation. 2011;22:603-611. https://doi.org/10.1007/s10532-010-9433-1

35. US Environmental Protection Agency. Endocrine disruptor screening program (EDSP). 2012.

36. USEPA, U.S. Environmental Protection Agency, Endocrine Disruptor Screening Program, 2012.

37. Shi Y, Chai L, Tang C, et al. Biochemical investigation of kraft lignin degradation by Pandoraea sp. B-6 isolated from bamboo slips. Bioprocess Biosyst Eng. 2013; 36:1957-1965. https://doi.org/10.1007/s00449-0130972-9

38. TW Jeffries. Biodegradation of lignin-carbohydrate complexes. Biodegradation. 1990;1:163-176. https:// doi.org/10.1007/BF00058834

39. Peng W, Y Wu. Py-GC/MS analysis on benzene/ ethanol extractives of Eucalyptus camaldulensis wood meal in pulping wastewater from South China. Proceedings of conference on regional economy and sustainable development, ISBN. 2008;978-0-646-50352-3.

40. Shi S, Li K, YY Lee. Production of Lactic Acid from the Mixture of Softwood Pre-hydrolysate and Paper Mill Sludge by Simultaneous Saccharification and Fermentation. Appl Biochem Biotechnol. 2015;175:2741-2754. https://doi.org/10.1007/ s12010-014-1451-8

41. Liu X, Zhu H, Qin C, Zhou J, Zhao JR, S Wang. Adsorption of heavy metal ion from aqueous single metal solution by aminated epoxy-lignin. Bioresource. 2013;8:22572269. https://doi.org/10.15376/biores.8.2.2257-2269

42. Demirbas A. Adsorption of Co (II) and $\mathrm{Hg}$ (II) from water and wastewater onto modified lignin. Energy Sources. 2007;2:117-123. https://doi. org/10.1080/009083190948720

43. Cheng J, Yu SM, P Zuo. Horseradish peroxidase immobilized on aluminium-pillared interlayered clay for the catalytic oxidation of phenolic wastewater. Water Research. 2006;40:283-290. https://doi. org/10.1016/j.watres.2005.11.017

44. Haq I, Kumar S, Raj A, Lohani M, GNV Satyanarayana. Genotoxicity assessment of pulp and paper mill effluent before and after bacterial degradation using Allium cepa test. Chemosphere. 2017;169:642-650. https://doi.org/10.1016/j.chemosphere.2016.11.101 45. Reveille V, Mansuy L, Jarde, E Garnier-Sillam. Characterization of sewage sludge-derived organic matter: lipids and humic acids. Organic Geochemistry. 2003;34:615-627. https://doi. org/10.1016/S0146-6380(02)00216-4 